\title{
TANGGAP BENCANA, SOLUSI PENANGGULANGAN KRISIS PADA ANAK
}

\author{
Nur Hidaayah \\ (UNUSA, FIK, Prodi SI Keperawatan - Jl. Smea 57 Surabaya) \\ Email : nur_hidy@yahoo.co.id
}

\begin{abstract}
The crisis is condition changes that occur unexpectedly due to an unpleasant event and create an imbalance of physical, psychological, socio, spiritual. Crises caused by the disaster can be experienced by anyone either elderly to children. Crisis in children become focused in all disaster management activities, because they most feel the effects of the disaster. The impact of a farewell with a loved one, loss of a limb or disability, and death. Destruction of residence, place of learning (schools) as well as several other important facilities to make the failure of the subsequent development of the child. Failures development in question is a child who should not be riding classes, riding classes pursued because of social pressures. As a result, it is less able to master learning tasks in class so as to produce negative self concept.
\end{abstract}

\begin{abstract}
Abstrak : Krisis merupakan perubahan kondisi yang terjadi tanpa terduga akibat suatu peristiwa yang tidak menyenangkan dan membuat ketidakseimbangan fisik, psikis, sosio, spiritual. Krisis akibat bencana dapat dialami oleh siapapun baik lansia sampai anakanak. Krisis pada anak menjadi fokus di semua kegiatan penanggulangan bencana, karena mereka paling merasakan dampak setelah bencana. Dampak tersebut berupa perpisahan dengan orang yang dicintai, kehilangan anggota tubuh atau kecacatan serta kematian. Musnahnya tempat tinggal, tempat belajar (sekolah) serta beberapa fasilitas penting lainnya menjadikan kegagalan perkembangan selanjutnya bagi anak. Kegagalan perkembangan yang dimaksud adalah anak yang seharusnya tidak naik kelas, diupayakan naik kelas karena adanya tekanan-tekanan sosial. Akibatnya, ia kurang mampu menguasai tugas-tugas belajar di kelasnya sehingga menghasilkan konsep diri yang negatif.
\end{abstract}

Kata kunci : Bencana, solusi, penanggulangan, anak

\section{PENDAHULUAN}

Berbagai bencana yang terjadi di wilayah Indonesia disebabkan karena letak geografisnya. Karakteristik daerah rawan bencana antara lain, pesisir pantai, pegunungan, pemukiman padat, pinggiran sungai, jalur gempa, serta gedung tinggi. Beberapa bencana alam yang pernah terjadi yaitu : banjir, tanah longsor, gunung meletus, gempa bumi, tsunami dan angin puting beliung. Namun masih banyak juga terjadi bencana yang bukan disebabkan karena faktor alam, misalnya konflik sosial, terorisme, kebakaran dan kecelakaan. Dasyatnya kerusakan yang ditimbulkan saat bencana membuat manusia mengalami trauma fisik dan psikis, sehingga menyebabkan keadaan krisis.
Bencana menurut UU no.24 Tahun 2007 diartikan sebagai peristiwa atau rangkaian peristiwa yang mengancam dan mengganggu kehidupan dan penghidupan masyarakat yang disebabkan oleh faktor alam dan/atau faktor non alam maupun faktor manusia sehingga mengakibatkan timbulnya korban jiwa manusia, kerusakan lingkungan, kerugian harta benda dan dampak psikologis.

Data jumlah korban gempa bencana alam terbesar di Indonesa yaitu tsunami di propinsi NAD (Nangroe Aceh Darussalam) tahun 2004 tercatat korban paling banyak diantara 13 negara, sekitar 115.229 jiwa. Disusul kemudian tanah longsor di Propinsi Sumatera Barat pada tahun 2009, korban meninggal sebanyak 603 orang, hilang 343 orang, luka berat 
sebanyak 412 orang, luka ringan 2.093, korban yang masih tertimbun berjumlah ratusan orang, jumlah pengungsi sebanyak 736 jiwa, dan mayoritas dari korban yang mengalami trauma adalah anak-anak. Hingga bencana gunung Sinabung yang meletus tahun 2014 menurut informasi Badan Nasional Penanggulangan Bencana bahwa 4 desa yang terkena dampak erupsi, terdapat 17 orang meninggal termasuk didalamnya anak-anak.

Bagian masyarakat yang mengalami dampak paling buruk dari bencana adalah anak-anak. Mereka belum menyadari adanya bahaya, tidak mengetahui cara pencegahannya, tak mampu menanggulangi saat terjadi serta usaha memperbaiki setelah bencana tersebut berlalu. Ketidakmampuan anak terhadap beberapa tindakan tersebut dapat memicu terjadinya trauma. Trauma pada anak yang tidak segera ditanggulangi sering menimbulkan kondisi krisis bahkan tidak jarang muncul gangguan mental.

\section{Pencegahan maupun} penanggulangan dampak bencana terutama pada anak sangat diperlukan. Pertolongan pada kondisi krisis anak dapat dilakukan dengan menurunkan bahkan menghilangkan trauma fisik dan psikis. Bentuk pertolongan tersebut dapat berupa konseling (trauma, proses berduka, krisis, penyelesaian masalah) serta bimbingan antisipasi di Pos pengungsian sebagai bentuk trauma healing, dapat juga diberikan dalam pelajaran sekolah sebagai tindakan promotif dan preventif. Bantuan dari orang dewasa terutama tenaga kesehatan sangat dibutuhkan, demi kelangsungan hidup di masa yang akan datang.

\section{PEMBAHASAN}

Pembahasan tentang bencana dapat dipelajari berdasarkan 4 faktor penting dalam penanggulangan bencana menurut kesehatan jiwa. Penanggulangan bencana ini dapat dilakukan dengan dukungan beberapa pihak yaitu orangtua atau orang terdekat anak, guru, perawat, petugas kesehatan lain dan anak yang bersangkutan. Adapun empat faktor tersebut meliputi : kejadian krisis, identifikasi respon individu apabila mengalami bencana, manajemen bencana, serta tindakan yang dilakukan saat bencana. Berikut ini penjelasannya :

\section{Kejadian Krisis}

Kejadian pra bencana dapat diketahui bahwa anak dapat menjalankan kegiatan sehari-hari seperti, belajar di sekolah, bermain, ibadah dan istirahat. Setiap anak dimanapun berada hidup tanpa terpikir akan datang bencana. Kemudian mereka dikejutkan dengan adanya pengeras suara menginformasikan akan terjadi bencana dalam 24 jam mendatang harus segera meninggalkan tempatnya semula menuju area pengungsian. Bahkan bencana yang datang tiba-tiba sebelum melakukan persiapan, seperti kecelakaan, angin puting beliung, tanah longsor dan sebagainya. Hingga saat terjadi bencana, anak-anak mengalami luka fisik, kehilangan anggota tubuh, perpisahan dengan orangtua, kehilangan harta benda, perpisahan dengan orang yang dicintai bahkan kematian. Setelah bencana mereda dan berlalu, kondisi luka yang tertinggal baik fisik maupun psikis anak belum juga hilang dan disebut dengan kondisi krisis.

\section{Identifikasi respon individu}

Identifikasi respon individu dapat diamati dalam 3 periode yaitu respon segera dalam 24 jam, respon jangka pendek (minggu pertama sampai ketiga) dan respon jangka panjang (minggu keempat sampai setelah bencana). Respon segera meliputi : tegang, cemas, panik, bingung, tidak percaya, lelah, gelisah, sedih, menyendiri, merasa bersalah. Sedangkan respon jangka pendek meliputi: takut, mudah tersinggung, marah, sulit tidur, khawatir, sangat sedih, mengulang kembali cerita kejadian, menerima takdir, optimis, menolong dan menyelamatkan. Respon terakhir adalah respon jangka panjang meliputi: panik, sangat lelah, sedih berkepanjangan, tidak mau beraktivitas, menarik diri, cemas dengan manifestasi palpitasi, pusing, mual, sakit kepala. 


\section{Manajemen Bencana}

Manajemen bencana dibagi menjadi 3 tahap: tahap pra bencana, bencana dan pasca bencana. Tahap pra bencana, tindakan yang dilakukan adalah pencegahan, mitigasi (pemetaan). Tahap bencana, tindakan yang dilakukan adalah tanggap darurat. Sedangkan tahap pasca bencana, tindakan yang dilakukan adalah pemulihan, perbaikan dan penataan kembali serta mitigasi.

Tindakan pencegahan yang perlu diketahui anak adalah mengetahui tanda bencana dan upaya penyelamatan diri. Beberapa contoh tindakan bila terjadi gempa : segera berlindung di bawah meja, lindungi kepala saat berada dalam ruangan, jika berada di bangunan bertingkat segera berlari ke lantai yang lebih tinggi, selamatkan diri sendiri karena dapat menyelamatkan orang lain. Apabila terdapat tanda tsunami, hendaknya anak mampu mengenal tanda tsunami yaitu suara gemuruh tetapi tidak disertai hujan, air laut di pantai surut mendadak, bau belerang atau garam laut dapat tercium pada jarak yang sangat jauh dari pantai, serta bila sebelumnya didahului gempa berkekuatan besar.

$\begin{array}{llr}\text { Tindakan tanggap bencana yaitu } \\ \text { segera saat bencana } \\ \text { masyarakat } & \text { saling } & \text { membantu }\end{array}$ menyelamatkan diri, mencari bantuan dari luar daerah bencana sambil menuju tempat pengungsian yang aman. Saling mendukung mencari sumber komunikasi yanng masih ada, transportasi, pelayanan kesehatan untuk deteksi penyakit menular dan gangguan mental.

Tindakan pasca bencana yaitu pertama, pemulihan seluruh pihak bergerak bersama memperbaiki kondisi ekonomi dan kehidupan masyarakat. Penanganan maslah kesehatan oleh dinas kesehatan, LSM terkait, departemen pekerjaan umum dan lembaga terkait, keamanan melibatkan tentara dan kepolisian, pengadaan air bersih oleh PAM, kementrian kesejahteraan rakyat untuk pengadaan bantuan makanan, minuman, pakaian. Tindakan kedua, perbaikan meliputi pembangunan rumah tinggal, sarana umum yang rusak seperti sekolah, tempat ibadah. Tindakan ketiga, penataan kembali yaitu kembali bekerja seperti sebelum terjadi bencana. Tindakan keempat, mitigasi yaitu merencanakan kegiatan untuk masa mendatang terutama untuk mencegah terjadinya bencana sekunder dengan mengadakan program pelatihan ketrampilan kerja, pelatihan tanggap darurat bencana baik di masyarakat dan seluruh petugas kesehatan.

\section{Tindakan yang Dilakukan Saat Bencana}

Tindakan yang dilakukan untuk membantu korban bencana terbagi menjadi 3 fase :

a. Segera setelah bencana dalam waktu 24 jam : kerusakan lingkungan yang terjadi, derita yang dialami, kebutuhan dasar yang harus terpenuhi (makan, minum, pakaian dan tempat tinggal sementara atau pengungsian. Tindakan yang dibutuhkan adalah darurat masalah fisik, memenuhi kebutuhan dasar serta membantu para korban agar dapat kembali beraktifitas.

b. Minggu pertama sampai ketiga setelah bencana

Adanya akses lokasi jenazah, mendukung keluarga jika jenazah dimakamkan tanpa upacara terlebih dahulu, membantu mencari anggota keluarga yang terpisah pada individu yang beresiko, seperti lansia, ibu hamil, anak. Kegiatan berkelompok antara tim tanggap bencana dengan para korban, seperti ibadah atau doa bersama, kegiatan tersebut memberi ketenangan dan dukungan agar lebih kuat menerima musibah. Memisahkan korban anak-anak kemudian diberi terapi rekreasi atau trauma healing serta yakinkan pada mereka bahwa respon psikologis yang ditunjukkan bisa dialami oleh semua manusia dan perasaan itu hanya berlangsung sementara atau akan hilang dengan sendirinya.

c. Setelah minggu ketiga bencana Tindakan yang harus dilakukan pada minggu ketiga ini adalah pemberian konseling trauma, seperti mendengarkan ungkapan perasaan korban penuh perhatian, menggali (tanpa paksaan) 
pengalaman keberhasilan korban berusaha menyelamatkan korban lainnya serta diri sendiri. Anggota tim penolong dan korban saling berdiskusi tentang cara mengatasi masalah dan menyusun rencana kegiatan selanjutnya, hingga para korban dapat melangsungkan kegiatan seperti sebelum bencana.

Tindakan selanjutnya adalah konseling proses berduka, seperti bertanya dengan lembut tentang kondisi keluarga lainnya yang terpisah, belum ditemukan dan yang meninggal. Tim penolong bersama mereka kemudian mencari informasi keberadaan korban yang belum ditemukan dengan membawa dan menunjukkan foto anggota keluarga mereka yang hilang.

Tindakan berikutnya adalah bimbingan antisipasi yaitu menerima respon korban dan menyatakan respon tersebut normal ditunjukkan oleh semua orang, hal ini dapat mengurangi rasa keputusasaan dan ketidakberartian. Kegiatan ibadah dan doa bersama untuk semua korban yang ada, saling bertukar informasi tentang pencarian anggota keluarga yang hilang. Hal tersebut akan membuat mereka saling menguatkan perasaan dan dukungan menghadapi krisis bersama-sama. Berdiskusi tentang alternatif dan strategi mengatasi masalah, serta membantu mereka dapat memutuskan bersama secara tepat dan upaya pelaksanaan keputusan disertai identifikasi kemampuan yang dimiliki korban.

Tindakan bantuan terakhir adalah konseling untuk menyelesaikan masalah yaitu berkumpul bersama untuk curah pendapat tentang alternatif pemulihan, perbaikan tempat tinggal, pembangunan fasilitas umum secara gotong royong. Pemimpin diskusi hendaknya mengidentifikasi solusi yang paling sesuai untuk semua masyarakat dan upaya keberhasilan pelaksaanaannya.

\section{SIMPULAN}

1. Krisis merupakan perubahan kondisi yang terjadi tanpa terduga akibat suatu peristiwa yang tidak menyenangkan dan membuat ketidakseimbangan fisik, psikis, sosio, spiritual. Krisis akan berlalu seiring berjalannya waktu, namun perlu adanya pendampingan saat menghadapinya.

2. Trauma pada anak membutuhkan dukungan bersama untuk menanganinya, dukungan tersebut mengalir dari sosok guru, orangtua, anggota keluarga lainnya, tim kesehatan serta keterlibatan anak itu sendiri.

3. Pentingnya tindakan antisipasi pengurangan dampak trauma (krisis) pada anak dengan membekali mereka cara menyelamatkan diri dari bencana yang akan terjadi.

\section{DAFTAR RUJUKAN}

Anthony (2014). Linda Gumelar : Trauma Healing, Cara Tepat Untuk Kembalikan Keceriaan Anak-Anak.

http://www.menegpp.go.id/v2/index .php/component/content/ article/12anak/561-linda-gumelar-traumahealing-cara-tepat-untukkembalikan-keceriaan-anak-anak. Diakses tanggal 03- 01- 2014.

Cox, Erin and Briggs, Susan (2004). Disaster Nursing New Frontiers for Critical Care.

http://ccn.aacnjournals.org/content/2 4/3/16.long. diakses tanggal 03-012014

Keliat, Budi Anna dan Akemat (2009). Model Praktik Keperawatan Profesional Jiwa. EGC. Jakarta.

Linda Carman Copel (2007). Kesehatan Jiwa dan Psikiatri, Pedoman Klinis Perawat. EGC. Jakarta.

Nurul Hartini (2010). Bencana Tsunami dan Stres Pasca Trauma pada Anak. Volume 22, Nomor 3:259264. Jurnal Masyarakat Kebudayaan dan Politik. Fakultas Psikologi. Unair. 
